NOTE

\title{
Fate of bacteria transiting the gut of the deposit feeder Abarenicola pacifica: influence of temperature and sediment food concentration
}

\author{
Sabrina N. Hymel ${ }^{1, *}$, Craig J. Plante ${ }^{2, * *}$ \\ ${ }^{1}$ Graduate Program in Marine Biology, and ${ }^{2}$ Department of Biology, Grice Marine Laboratory, University of Charleston, \\ 205 Fort Johnson Road, Charleston, South Carolina 29412, USA
}

\begin{abstract}
Deposit-feeding macrofauna can substantially impact sedimentary bacteria, both by bioturbative activities and removal during gut passage. Laboratory feeding experiments were conducted with the deposit feeder Abarenicola pacifica (Polychaeta: Arenicolidae; Healy and Wells) to test for separate and interactive effects of sediment food concentration and temperature on bacterial gut passage. Food concentration was varied via dilution of ambient sediments and measured as: (1) enzyme hydrolyzable amino acids (EHAA), (2) chlorophyll a (chl a), and (3) bacterial abundance. Gut bacteria were quantified via direct counts of sediments from 3 morphologically distinct gut regions (foregut [FG], midgut [MG], hindgut [HG]), and compared with ambient sediments (SD). Changes in bacterial abundance among these 'locations' were converted to percentage data (selection, digestion and growth). Generally, FG bacterial abundances were significantly greater than SD abundances, suggesting selection for bacteria-rich fractions of sediment. The magnitude of selection was significantly greater in sediments with low food concentrations. Significant digestion occurred in the MG, although efficiencies were lower than previously reported for similar deposit feeders. Contrary to earlier findings with other arenicolids, bacterial growth in the HG was slight, and significant only at high food concentrations. Temperature did not significantly affect removal of bacteria in the gut. Feeding rates (i.e., egestion rates) co-varied with selection, and temperature-specific patterns were observed. Our results agree with earlier studies in that the bacteria-rich fractions of sediments may be preferentially selected by deposit feeders, particularly under conditions of low food concentration. This has important implications for sediment bacteria, especially when removal efficiencies remain constant, and HG growth is low. Additionally, we expect that increased feeding rates, digestive efficiencies and HG growth under high food conditions will lead to greater qualitative impacts on sedimentary bacteria.
\end{abstract}

KEY WORDS: Sediment $\cdot$ Bacteria $\cdot$ Deposit feeder $\cdot$ Gut passage $\cdot$ Abarenicola pacifica

Resale or republication not permitted without written consent of the publisher

* Present address: Department of Biological Sciences, Louisiana State University, Baton Rouge, Louisiana 70803, USA

**Corresponding author. E-mail: plantec@cofc.edu
The importance of deposit feeders to bacterial communities has been of considerable interest to investigators for 2 primary reasons: (1) to determine how sediment reworking rates (i.e., feeding rates) affect transport of detritus, oxygen and nutrients, and thus bacterial production (e.g., Hylleberg 1975, Grossman \& Reichardt 1991); and (2) to determine how removal of bacteria quantitatively (Juniper 1981, Findlay \& White 1983) and qualitatively (Dobbs \& Guckert 1988, Plante \& Mayer 1994) impacts community structure. As a consequence of differential digestion/regrowth, gut passage has been shown to alter bacterial community composition relative to that found in surrounding sediments (Dobbs \& Guckert 1988, Plante \& Jumars 1993). Given the importance of sedimentary bacteria to biogeochemical processes, the resulting impact of deposit-feeding activities on bacterial communities can be profound.

Seasonal changes in temperature and/or food (i.e., detrital) concentrations affect bacterial production (Cammen \& Walker 1986, Moriarty 1989, Danovaro et al. 1994) as well as deposit-feeder production (Levinton \& Stewart 1988), sediment processing rates (Hobson 1967, Retraubun et al. 1996), and physiological functions such as gut bacteriolysis (Plante \& Mayer 1996, Lucas \& Bertru 1997). However, we know of no studies which have experimentally addressed separate and interactive effects of temperature and food concentration on the fate of sedimentary bacteria ingested by deposit feeders. These questions are particularly compelling in light of previous field studies (e.g., Plante \& Mayer 1996) which suggest that interactions between deposit feeders and sedimentary bacteria vary seasonally.

Feeding experiments, in which food concentration and temperature were manipulated under controlled 
laboratory conditions, were conducted using the arenicolid polychaete Abarenicola pacifica (Healy and Wells). We discuss A. pacifica's functional (feeding rate) and physiological (bacteriolytic rate) responses in another paper (Hymel \& Plante 2000). Here, we discuss how temperature and food concentration affected sedimentary bacteria transiting the gut of A. pacifica.

Materials and methods. Large, adult Abarenicola pacifica were collected during early June 1997 from mud flats near the Coos Bay estuary in Oregon, approximately $1 \mathrm{~m}$ above MLLW. Water temperatures ranged from 9 to $15^{\circ} \mathrm{C}$, but were generally 11 to $13^{\circ} \mathrm{C}$ (B. Hentschel \& C. Czeilsa pers. comm.). Worms were shipped overnight to the Grice Marine Laboratory, Charleston, SC, and maintained on sediments collected from nearby Pawleys Island, SC, for a period of 1 to 2 wk under standard conditions $\left(11^{\circ} \mathrm{C}, 30\right.$ to 33 psu, pH 7.8 to $8.0,12 \mathrm{~h}$ light:12 h dark cycle) until feeding experiments were conducted (11 to 21 July 1997). A randomized complete block design of 3 temperatures $\left(6,11\right.$, and $\left.16^{\circ} \mathrm{C}\right)$ by 3 food concentrations $(25,50$, and $100 \%$ natural sediment $)$ by 12 replicates/treatment was implemented over a $10 \mathrm{~d}$ acclimation period, followed by a $5 \mathrm{~d}$ experimental run.

The top 3 to $5 \mathrm{~cm}$ of oxic sediment was collected from a shallow lagoon near Pawleys Island on 5 consecutive days from 10 to 14 July 1997. Sediments were primarily composed of well-sorted, medium-to-fine sands ( $\mathrm{Md} \Phi=2.00 ; 0.6 \%$ organic). Sediments were combined and sieved through a $1 \mathrm{~mm}$ mesh screen to remove macrofauna and large debris. A portion of this was dried $\left(60^{\circ} \mathrm{C}\right)$, combusted at $500^{\circ} \mathrm{C}$ for $8 \mathrm{~h}$, and rinsed to remove fine particulates. The remaining sieved sediments were diluted as wet $\mathrm{v} / \mathrm{v}$ mixtures to 50 and $25 \%$ natural:combusted sediment, and thoroughly homogenized. Approximately $500 \mathrm{ml}$ (wet volume) of the respective sediment mixtures was added to individual plastic freezer containers $(\sim 11)$. Water temperatures for each treatment $\left(6,11\right.$ or $\left.16^{\circ} \mathrm{C}\right)$ were controlled within 1 to $2^{\circ} \mathrm{C}$ using 3 closed-loop recirculating water baths. Salinity ranged from 30 to $33 \mathrm{psu}$, and $\mathrm{pH}$ from 7.8 to 8.0 . A $12 \mathrm{~h}$ light: $12 \mathrm{~h}$ dark cycle was maintained throughout the experiment.

Sediment samples were removed via individual $1 \mathrm{ml}$ syringe corers (surface to $\sim 2 \mathrm{~cm}$ depth) from haphazardly selected locations within each container. Baseline $(t=-10 \mathrm{~d})$ samples of food concentration variables (i.e., enzyme hydrolyzable amino acids [EHAA], chlorophyll a $\left[\begin{array}{cc}\mathrm{chl} & \mathrm{a}\end{array}\right]$, bacterial abundance) were taken prior to the addition of worms. For EHAA analysis, sediment cores $(2 \times 0.2 \mathrm{ml})$ were placed into $1.7 \mathrm{ml}$ polypropylene centrifuge tubes and immediately frozen $\left(-20^{\circ} \mathrm{C}\right)$ until further analysis. Pigment cores $(2 \times$ $0.5 \mathrm{ml})$ were frozen $\left(-20^{\circ} \mathrm{C}\right)$ in glass vials after the addition of $10 \mathrm{ml}$ of $90 \%$ HPLC-grade acetone until pig- ment analysis. Bacterial abundance cores $(2 \times 0.5 \mathrm{ml})$ were immediately fixed in ice-cold, phosphate-buffered glutaraldehyde $\left(\mathrm{GTA}^{\circ} 4 \%\right)$ and refrigerated $\left(4^{\circ} \mathrm{C}\right)$.

Worms were then haphazardly assigned among plastic containers that were then randomly assigned to tanks, and gently submerged to minimize sediment disturbance. Water temperatures for the 6 and $16^{\circ} \mathrm{C}$ treatments were gradually attained (from $11^{\circ} \mathrm{C}$ ) over a $48 \mathrm{~h}$ interval. Worms were allowed to acclimate to temperature and feeding conditions for $10 \mathrm{~d}$. At $t=0 \mathrm{~d}$, containers were retrieved, sampled as described above, and carefully resubmerged. Feeding and defecation activity was observed every $12 \mathrm{~h}$ for $5 \mathrm{~d}$, and fecal casts were collected via pipet, dried, and weighed.

At $t=5 \mathrm{~d}$, containers were again sampled and returned to aquaria until just prior to worm dissection. Worms were dissected asceptically after rinsing with filtered $(0.2 \mu \mathrm{m})$ seawater (FSW) to remove clinging sediment and mucus. A longitudinal cut was made through the body wall, and the viscera were gently rinsed with FSW. Midgut fluids were collected by syringe for the bacteriolytic assay (Plante \& Mayer 1994). Sediment samples were then collected from foregut (FG), midgut (MG) and hindgut (HG) regions (see Plante \& Jumars 1993 for descriptions of Abarenicola pacifica gut morphology).

Sediment food concentration was assayed as (1) EHAA (Mayer et al. 1995), (2) chl a (standard fluorimetric methods; Lorenzen 1966), and (3) direct counts of sediment bacterial abundance (Hymel \& Plante 1998). All bacterial direct counts were made under epifluorescence microscopy using the fluorochrome DAPI, as described in Hymel \& Plante (1998). Bacterial abundances were normalized to dry weights of sediments (cells $g$ dry $\mathrm{wt}^{-1}$ ).

Data that failed to meet assumptions of normality (graphical methods, Sokal \& Rohlf 1995) or homoscedasticity $\left(F_{\max }\right.$ test) were either square-root-transformed or natural-log-transformed. Blocks (i.e., aquaria) were excluded from ANOVA models after univariate tests ruled out block effects. A data matrix was constructed by matching replicates from $t=5 \mathrm{~d}$ sediment bacterial abundances with gut bacterial abundances. However, as it was not always possible to collect and/or process gut sediments from each gut section (FG, MG, HG) for each replicate, the resulting matrix was not uniform. This precluded the use of autocorrelative statistical measures that would test for interdependent changes in gut abundance across treatment groups, and therefore all gut sections were assumed independent units for subsequent analyses. One-way ANOVA was initially carried out on log-transformed variates to test for changes in bacterial abundance between sediment (SD), FG, MG, and HG (i.e., effect of 'location'). As a 
few influential points were discovered upon examination of residuals, Kruskal-Wallis (K-W) tests were also performed; we report the more conservative of these 2 tests. Bonferroni tests were used to identify differences between pairs of means at an experimental $\alpha$ of 0.05 .

Percent changes in bacterial abundances were calculated, and the terminology of Plante \& Jumars (1993) was adopted. 'Selection' was defined as the percent increase in abundance from SD to FG, 'digestion' as the percent decrease in abundance from FG to MG, and 'growth' the percent increase from MG to HG. These values were calculated from matched replicates from the original data matrix discussed previously. However, since it was not always possible to calculate selection, digestion and growth measures for each replicate, each measure was considered an independent unit for analyses.

The direction of each percentage measure was presumed to be positive. However, individual as well as mean percentages were often negative; that is, some values were counter to the expected direction of change (Plante \& Jumars 1993). As a result, traditional data transformation techniques (e.g., arcsine) were not performed. Because both treatment effects were fixed and randomized, the Scheirer et al. (1976) modification of the K-W ANOVA was used, by which rank-transformed data were analyzed via 2-way ANOVA. Posthoc comparisons were carried out with a Bonferroni adjustment as described previously. Detailed descriptions of analyses of feeding rates and bacteriolytic rates of Abarenicola pacifica are presented in Hymel \& Plante (2000).

Results. At $t=-10 \mathrm{~d}$, all 3 variables were proportional to the amount of natural sediment present (Table 1). By $t=0 \mathrm{~d}, \mathrm{chl} a$ and EHAA had decreased significantly, and had undergone a shift in relative proportions with respect to temperature and sediment mixture (Table 1). No further significant changes in EHAA proportions were measured by $t=5 \mathrm{~d}$ (Table 1 ); unfortunately, all $t=5 \mathrm{~d}$ samples for chl $a$ were lost prior to processing. There was no net change in bacterial abundance over time, due in part to an increase in bacterial abundance for the $25 \%$ sediment mixture that offset decreases in 50 and $100 \%$. All 3 sediment variables were significantly and positively correlated with each other (data not shown), although the strength of these relationships decreased somewhat over time.

Table 1. Means \pm SE (n) for sediment food concentration variables. $\%=$ percent natural sediment, chl $a=$ chlorophyll $a$, EHAA $=$ enzyme hydrolyzable amino acids, $\mathrm{BA}=$ bacterial abundances, na $=$ data not available

\begin{tabular}{|c|c|c|c|c|c|}
\hline Day & $\begin{array}{c}\text { Temperature } \\
\left({ }^{\circ} \mathrm{C}\right)\end{array}$ & $\%$ & $\begin{array}{c}\text { Chl } a \\
\text { ( } \operatorname{ug~g}^{-1} \text { sediment) }\end{array}$ & $\begin{array}{c}\text { EHAA } \\
\left.\text { (mg g }{ }^{-1} \text { sediment }\right)\end{array}$ & $\begin{array}{c}\text { BA } \\
\left(10^{6} \text { cells g }^{-1}\right)\end{array}$ \\
\hline-10 & 6 & 25 & $6.4 \pm 0.6(10)$ & $0.138 \pm 0.015(6)$ & $57 \pm 10(6)$ \\
\hline-10 & 6 & 50 & $9.8 \pm 0.5(10)$ & $0.183 \pm 0.010$ & $98 \pm 13(6)$ \\
\hline-10 & 6 & 100 & $15.1 \pm 0.9(11)$ & $0.272 \pm 0.009(6)$ & $177 \pm 20(6)$ \\
\hline-10 & 11 & 25 & $7.0 \pm 0.6(10)$ & $0.131 \pm 0.008$ & $67 \pm 16(6)$ \\
\hline-10 & 11 & 50 & $9.8 \pm 0.4(10)$ & $0.195 \pm 0.020$ & $99 \pm 11(6)$ \\
\hline-10 & 11 & 100 & $14.1 \pm 1.5$ & $0.322 \pm 0.020$ & $190 \pm 26(6)$ \\
\hline-10 & 16 & 25 & $6.0 \pm 0.1(10)$ & $0.105 \pm 0.015$ & $49 \pm 8(6)$ \\
\hline-10 & 16 & 50 & $10.5 \pm 0.3(10)$ & $0.177 \pm 0.009(6)$ & $103 \pm 12(5)$ \\
\hline-10 & 16 & 100 & $15.5 \pm 0.9(9)$ & $0.218 \pm 0.027$ & $183 \pm 21(6)$ \\
\hline 0 & 6 & 25 & $6.0 \pm 0.6(9)$ & $0.111 \pm 0.006(6)$ & $76 \pm 5(6)$ \\
\hline 0 & 6 & 50 & $8.4 \pm 0.6(10)$ & $0.152 \pm 0.020(6)$ & $97 \pm 8(8)$ \\
\hline 0 & 6 & 100 & $14.6 \pm 0.3(10)$ & $0.225 \pm 0.015(6)$ & $158 \pm 15(8)$ \\
\hline 0 & 11 & 25 & $4.2 \pm 0.1(10)$ & $0.102 \pm 0.005(6)$ & $65 \pm 6(8)$ \\
\hline 0 & 11 & 50 & $5.9 \pm 0.4(10)$ & $0.149 \pm 0.011$ & $70 \pm 8(8)$ \\
\hline 0 & 11 & 100 & $9.0 \pm 0.5(10)$ & $0.326 \pm 0.046(6)$ & $137 \pm 12(8)$ \\
\hline 0 & 16 & 25 & $4.4 \pm 0.5(10)$ & $0.075 \pm 0.012$ & $67 \pm 5(8)$ \\
\hline 0 & 16 & 50 & $7.4 \pm 0.6(10)$ & $0.127 \pm 0.016(6)$ & $84 \pm 9(8)$ \\
\hline 0 & 16 & 100 & $10.7 \pm 0.4(10)$ & $0.231 \pm 0.028(6)$ & $167 \pm 18(8)$ \\
\hline 5 & 6 & 25 & na & $0.107 \pm 0.011$ & $76 \pm 3(7)$ \\
\hline 5 & 6 & 50 & na & $0.153 \pm 0.012(6)$ & $112 \pm 7(8)$ \\
\hline 5 & 6 & 100 & na & $0.264 \pm 0.007(6)$ & $167 \pm 30(6)$ \\
\hline 5 & 11 & 25 & na & $0.096 \pm 0.011$ & $53 \pm 6(8)$ \\
\hline 5 & 11 & 50 & na & $0.138 \pm 0.009(6)$ & $79 \pm 7(7)$ \\
\hline 5 & 11 & 100 & na & $0.277 \pm 0.019$ & $160 \pm 25(9)$ \\
\hline 5 & 16 & 25 & na & $0.068 \pm 0.010$ & $78 \pm 5(8)$ \\
\hline 5 & 16 & 50 & na & $0.078 \pm 0.010$ & $99 \pm 10(10)$ \\
\hline 5 & 16 & 100 & na & $0.228 \pm 0.022$ & $159 \pm 26(8)$ \\
\hline
\end{tabular}


Fig. 1 illustrates trends in gut bacterial abundance among locations for the entire pooled data set, by temperature and by food concentration. For the entire pooled data set (Fig. 1a) bacterial abundance was significantly different among locations ( $p<<0.001)$. Foregut (FG) bacterial abundance was significantly greater than sediment (SD), midgut (MG), or hindgut (HG) abundances ( $p<<0.001)$. However, there were no differences among SD, MG or HG abundances.

The data set was then partitioned according to temperature (Fig. 1b). For $6^{\circ} \mathrm{C}, \mathrm{FG}$ abundance was significantly greater than MG (p $<<0.001)$ and HG $(\mathrm{p}=$ $0.002)$, but not different than $\mathrm{SD}(\mathrm{p}=0.21)$. Mean abundances for SD, MG, and $\mathrm{HG}$ were statistically indistinguishable. Pairwise comparisons of bacterial abundances among gut locations at $11^{\circ} \mathrm{C}$ indicated that FG abundance was significantly greater than all other locations ( $p<0.001$ ), yet abundances among $\mathrm{SD}, \mathrm{MG}$ and $\mathrm{HG}$ did not differ. Results for $16^{\circ} \mathrm{C}$ were identical to those of $11^{\circ} \mathrm{C}$ both in treatment effect $(\mathrm{p}<<$ 0.001) and pairwise comparisons.
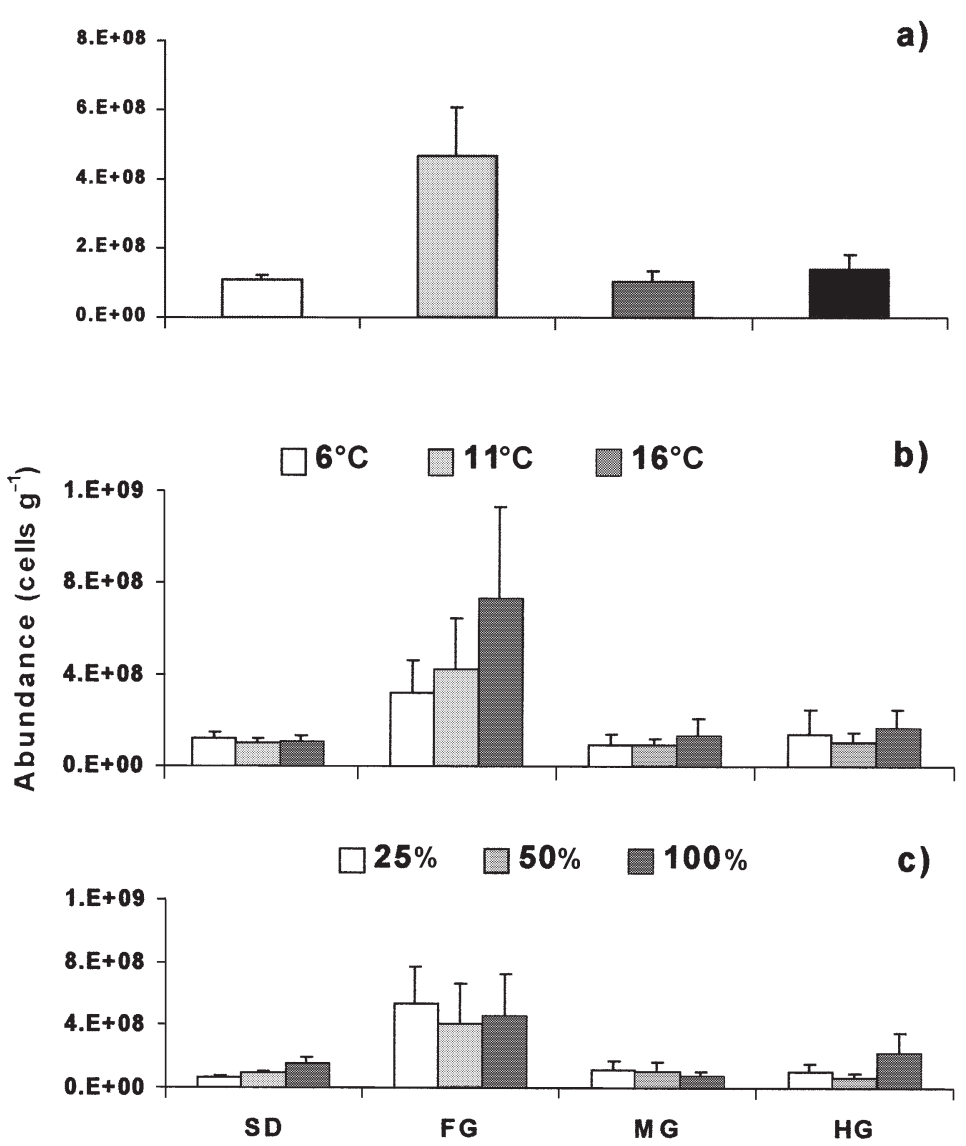

Fig. 1. Bacterial abundance (means $+1 \mathrm{SE}$ ) in sediment (SD) as well as the foregut (FG), midgut (MG) and hindgut (HG) regions of Abarenicola pacifica: (a) all treatments combined, (b) data partitioned by temperature $\left({ }^{\circ} \mathrm{C}\right)$, and (c) data partitioned by sediment mixture $(\%$ natural:combusted)
Data were next partitioned according to sediment concentration (Fig. 1c). For the $25 \%$ treatment, FG abundances were significantly greater than $\mathrm{SD}, \mathrm{MG}$ and HG abundances ( $p<<0.001$ ), yet there was no difference among SD, MG or HG abundances. Similar trends for $50 \%$ sediment concentration indicated that FG abundance was much greater than MG $(p=0.006)$ and HG ( $p<<0.001)$ abundances. There was a smaller, yet significant difference between FG and SD abundances ( $p=0.04$ ), although SD, MG and HG abundances were not statistically distinguishable. For $100 \%$ sediment concentration, FG abundance was significantly greater than MG ( $p<<0.001)$, HG $(p=0.02)$, and sediment $(p=0.05)$ abundances. SD abundance was significantly greater than MG abundance $(p=0.007)$, but not different from HG abundance ( $p=0.995)$. A significant increase in $\mathrm{HG}$ versus $\mathrm{MG}$ abundance $(\mathrm{p}=$ 0.02) was also detected.

Mean gut bacterial abundances, and results of ANOVA and K-W tests, for individual treatment groups (e.g, $6^{\circ} \mathrm{C}, 25 \%$ sediment mixture) are summarized in Table 2. Analyses within each treatment group tended to result in patterns similar to those described above for the main effects. Generally, an increase in abundance was found from SD to FG, a decrease from FG to $M G$, and a slight to pronounced increase from $\mathrm{MG}$ to $\mathrm{HG}$.

It was not always possible to calculate a percent change in bacterial abundance (i.e., selection, digestion, growth) for each replicate. In addition, individual values were often negative, indicating the reverse of the expected direction. Thus, when replicates are averaged, the mean percent change in abundance (e.g., digestion) appears to conflict with the actual mean abundances presented in Table 2 .

Though highly variable, overall selection was $538 \%$ (Fig. 2a). Temperature did not have a significant impact $(\mathrm{p}=0.25)$, although it appeared that selection was lowest at $6^{\circ} \mathrm{C}$ (Fig. 2b). Sediment mixture, however, had a significant effect $(p=0.023)$, and selection was significantly greater in the $25 \%$ than in the $100 \%$ treatments $(p=0.033)$. Mean selection for the $25 \%$ treatments was marginally greater than that of $50 \%$ treatments $(\mathrm{p}=0.073)$ (Fig. 2c). No difference was found between 50 and $100 \%$ treatments $(p=0.997)$. There was no significant interaction between temperature and sediment mixture $(\mathrm{p}=0.170)$.

Mean overall digestion was $20 \%$ (Fig. 2a). No significant effect of temperature was found for digestion $(p=0.970)$, and no apparent 
Table 2. Means $\pm 1 \mathrm{SE}(\mathrm{n})$ of bacterial abundances $\left(10^{6} \mathrm{~g}^{-1}\right)$ for $t=5 \mathrm{~d}$ in sediment (SD) and in the foregut (FG), midgut (MG), hindgut (HG) sections of Abarenicola pacifica. Mixture: percent natural sediment mixture. Significance values from 1-way ANOVA and Kruskal-Wallis (K-W) tests on 'location' are shown

\begin{tabular}{|c|c|c|c|c|c|c|c|}
\hline $\begin{array}{l}\text { Temperature } \\
\left({ }^{\circ} \mathrm{C}\right)\end{array}$ & $\begin{array}{c}\text { Mixture } \\
(\%)\end{array}$ & SD bacteria & FG bacteria & MG bacteria & HG bacteria & ANOVA & K-W \\
\hline 6 & 25 & $76 \pm 3(8)$ & $382 \pm 128$ & $93 \pm 58(9)$ & $106 \pm 50.1(12)$ & 0.014 & 0.023 \\
\hline 6 & 50 & $112 \pm 7(6)$ & $236 \pm 106(9)$ & $106 \pm 41$ & $83 \pm 18(8)$ & 0.160 & 0.180 \\
\hline 6 & 100 & $167 \pm 30$ & $361 \pm 145(7)$ & $74 \pm 16(7)$ & $240 \pm 153(9)$ & 0.057 & 0.030 \\
\hline 11 & 25 & $53 \pm 6(7)$ & $622 \pm 140$ & $108 \pm 20(7)$ & $98 \pm 25(8)$ & $<<0.001$ & 0.002 \\
\hline 11 & 50 & $79 \pm 7(9)$ & $230 \pm 280$ & $105 \pm 46$ & $63 \pm 15(8)$ & 0.043 & 0.090 \\
\hline 11 & 100 & $160 \pm 25(8)$ & $241 \pm 57(10)$ & $66 \pm 10(7)$ & $166 \pm 41$ & 0.005 & 0.010 \\
\hline 16 & 25 & $78 \pm 53(10)$ & $652 \pm 276(7)$ & $169 \pm 55(7)$ & $128 \pm 24$ & 0.002 & 0.006 \\
\hline 16 & 50 & $99 \pm 10(8)$ & $535 \pm 265$ & $131 \pm 72$ & $76 \pm 27(6)$ & 0.097 & 0.240 \\
\hline 16 & 100 & $159 \pm 26$ & $1060 \pm 454$ & $102 \pm 44$ & $286 \pm 105(7)$ & 0.006 & 0.029 \\
\hline
\end{tabular}

trends were observed (Fig. 2b). Sediment mixture significantly influenced digestion $(\mathrm{p}=0.002)$, and $100 \%$ treatments were significantly greater than $50 \%$ treatments ( $p=0.014$; Fig. 2c). There was no difference in digestion between 25 and $100 \%$ treatments $(\mathrm{p}=0.996)$, whereas the mean difference between 25 and $50 \%$ treatments trended toward significance $(\mathrm{p}=0.080)$.

Mean overall growth (from MG to HG) was $73 \%$ (Fig. 2a). Temperature did not significantly affect growth $(p=0.69$; Fig. 2b), but an overall significant effect of sediment mixture was observed $(\mathrm{p}=0.032$; Fig. 2c). Pairwise comparisons indicated that growth in the $50 \%$ treatment was not different from that in the $25 \%$ treatment $(p=0.61)$, but was significantly lower than that in the $100 \%$ treatment $(p=0.028)$. No differences were found between the 25 and $100 \%$ treatments $(p=0.370)$.

Discussion. The influences of temperature and sediment mixture on Abarenicola pacifica feeding rates (i.e., egestion rates, ER) are described in Hymel \& Plante (2000). We present here trends suggesting that ER and percent change in bacterial abundance co-varied with respect to temperature and sediment mixture. For all 3 temperatures, low feeding rates coincided with the greatest amount of selection. With increasing food concentration, temperature-specific patterns emerged. At $6^{\circ} \mathrm{C}$, ER peaked at $50 \%$ natural sediment, while selection dropped sharply (Fig. 3a). Selection at $6^{\circ} \mathrm{C}$ remained unchanged at $100 \%$ natural sediment, although ER declined. The linear decrease in selection with increasing food concentration at $11^{\circ} \mathrm{C}$ was mir-
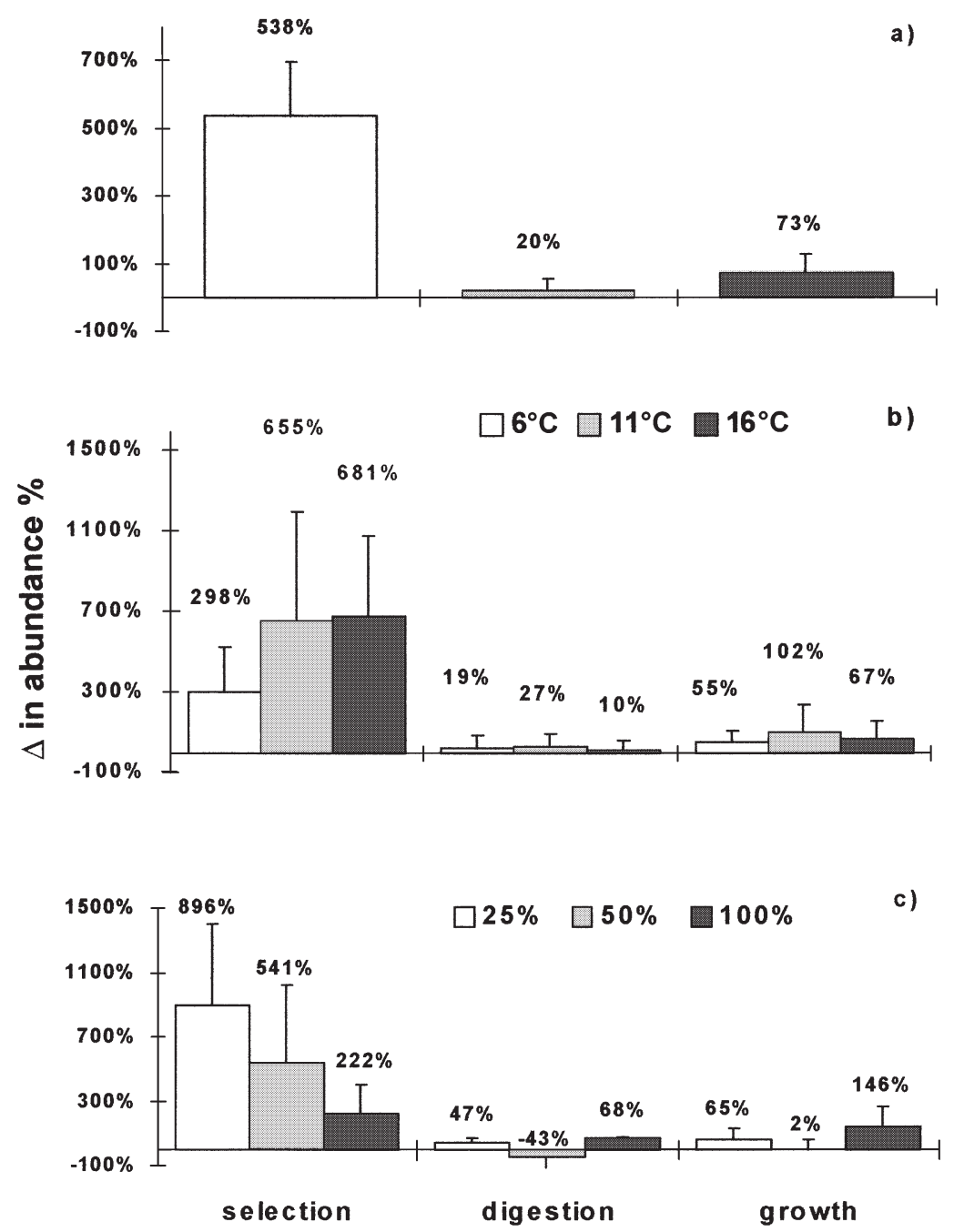

Fig. 2. Mean (+1 SE) percent change in bacterial abundance (a) for all treatments combined, (b) within temperatures, and (c) within sediment mixtures. Selection = percent increase in abundance from SD to FG; digestion = percent decrease in abundance from $\mathrm{FG}$ to $\mathrm{MG}$; growth = percent increase from $M G$ to $\mathrm{HG}$ 

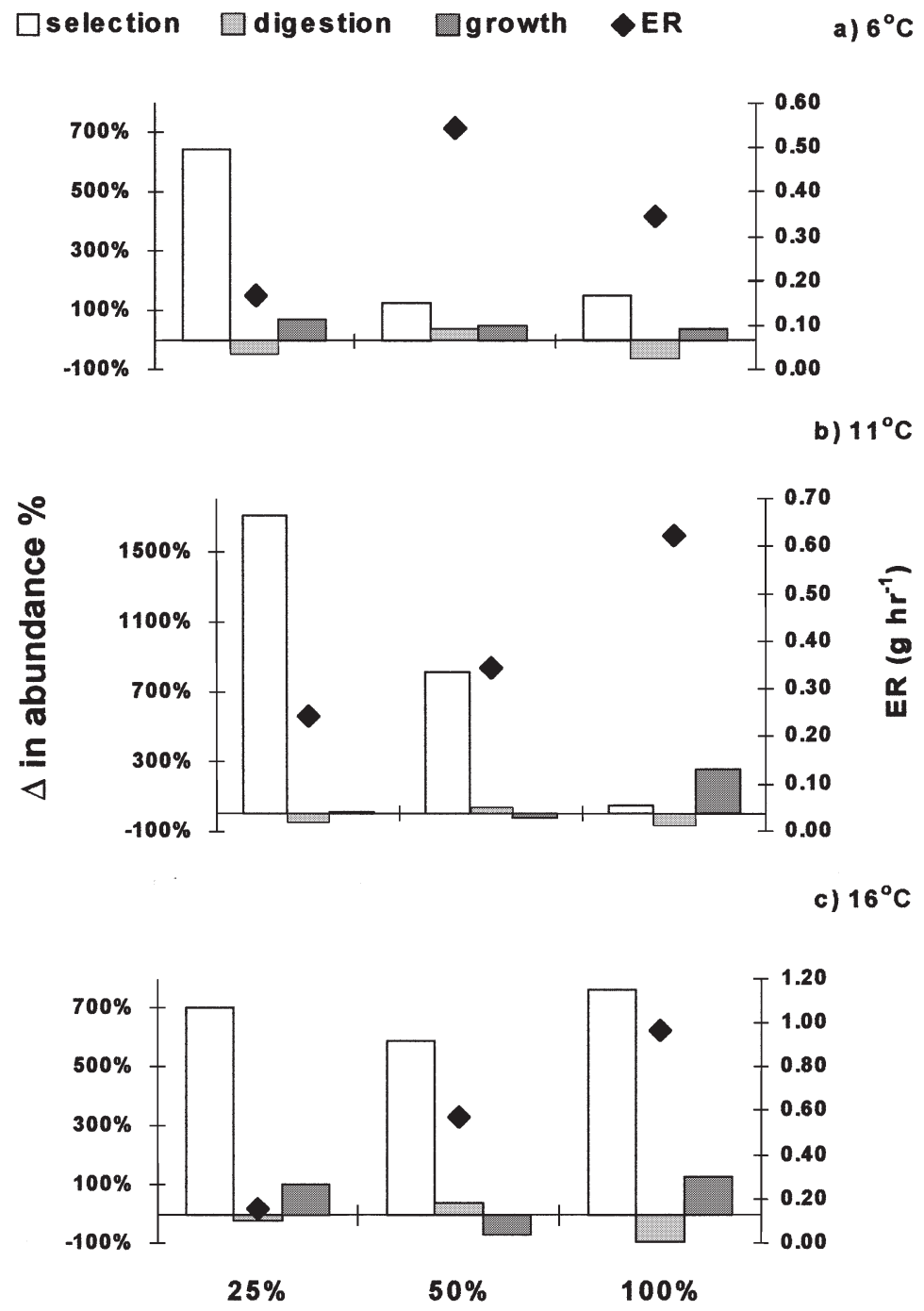

Fig. 3. Relationships between egestion rate (ER) and percent change in bacterial abundance. Error bars are omitted for clarity. 'Selection,' 'digestion' and 'growth' are as described in Fig. 2

rored by an increase in ER (Fig. 3b). Finally, although ER rose linearly with food concentration at $16^{\circ} \mathrm{C}$, selection was relatively constant among sediment mixtures (Fig. 3c). No obvious relationships between ER and either digestion or growth were observed.

Although no collective decrease in bacterial abundance was observed over time, there was a shift in the relative proportions among sediment concentrations. Bacterial abundance increased for the $25 \%$ treatments for all temperatures. Such increases might be attributed to increased surface area on uncolonized sediment grains (DeFlaun \& Mayer 1983). In addition, colonization from feces could have contributed to the increases observed (e.g., Newell 1965, C.J.P. \& S. Wilde unpubl.). Temperature effects trended toward significance, and suggested that bacterial numbers were somewhat lower for $11^{\circ} \mathrm{C}$ than for 6 or $16^{\circ} \mathrm{C}$.
Because feeding rates were higher for 11 versus $6^{\circ} \mathrm{C}$, greater numbers of bacteria may have been removed from $11^{\circ} \mathrm{C}$ sediments, although greater bacterial production would also be predicted at higher temperatures (Meyer-Reil et al. 1980, Ducklow 1983, Alongi 1988). Generally, results of this study support earlier findings of Kemp (1990) in that deposit feeders are unable to balance in situ bacterial production.

With the entire pooled data set, significant increases in FG abundance indicated substantial selection of bacteria from sediments. This agrees with earlier studies that have demonstrated that Abarenicola pacifica enhances bacterial consumption through selective feeding (Hylleberg 1975, Plante \& Jumars 1993). Selective feeding on bacteria has also been demonstrated in Arenicola marina (Grossman \& Reichardt 1991) and numerous other deposit feeders (Cammen 1980, Moriarty 1982, Bianchi \& Levinton 1984).

Although an overall case for selective feeding on bacteria can be made from the entire data set, this is not always the case when separate and interactive effects of temperature and food concentration are examined. For example, significant increases in bacterial abundance from $\mathrm{SD}$ to $\mathrm{FG}$ were observed for 11 and $16^{\circ} \mathrm{C}$, but not for $6^{\circ} \mathrm{C}$. However, while selection appeared lowest at $6^{\circ} \mathrm{C}$ (Fig. 1b), there was no significant temperature effect detected by analysis of ranked data. This conflicts with the findings of Plante \& Jumars (1993), whose results indicated that selection of bacteria by Abarenicola pacifica was reduced at extreme low $\left(7^{\circ} \mathrm{C}\right)$ and high $\left(24^{\circ} \mathrm{C}\right)$ seasonal temperatures observed in the field. However, a note of caution is advised when comparing the present work with their findings, because food concentration was not controlled in their field study, and sedimentary protein (i.e., EHAA) was relatively constant among sampling dates.

Trends in selective feeding with respect to sediment mixture were more straightforward, with significant increases in abundance from SD to FG noted for each group. Selection percentages, however, indicated an apparent inverse relationship with respect to food concentration. This seems reasonable in view of traditional optimal foraging theories that predict that as food resources become more abundant, selectivity is reduced (Hughes 1980). If deposit feeders are indeed limited by essential nutrients provided by bacterial biomass (Phillips 1984), then greater selection for bacteria would be predicted at low ambient abundances. 
The combined effects of temperature and sediment mixture upon selective feeding are less well defined. Significant increases in bacterial abundance between $\mathrm{SD}$ and FG were detected in only 3 of 9 temperature/ sediment mixture combinations (data not shown). Extremely high variability in FG abundances among individuals, as well as low replication within each treatment combination, potentially masked trends in abundance. It is thus difficult to define the interaction between the 2 main effects, although based on the above analyses, the influence of sediment mixture most likely outweighs that of temperature.

Finally, selective feeding can be examined with respect to feeding rate to discern whether a combination of strategies by deposit feeders might also enhance ingestion of bacteria. For example, in sediments with low bacterial abundance (and presumably, other food concentration parameters such as labile detritus and microalgae) animals might benefit by reducing sediment processing rates to select for a higher fraction of smaller (and thus, bacteriaenriched) particles. The present results support this hypothesis in that treatment combinations that resulted in lower feeding rates generally demonstrated high percent selection (Fig. 3). This was particularly evident at the intermediate temperature of $11^{\circ} \mathrm{C}$, where results suggested that a combination of feeding strategies was used to maximize gain with respect to food concentration.

Significant numerical losses between FG and MG indicated that, overall, bacteria were digested with modest efficiency $(20 \%)$. (It was assumed that the primary site of bacterial removal [i.e., the area of greatest bacteriolytic activity] was located in the MG of Abarenicola pacifica. This location has been predicted to minimize competition with bacteria for digestive products [Plante et al. 1990], and has further been identified in other arenicolids [e.g., Arenicola marina; Plante \& Mayer 1994].) Average digestion efficiencies of -26 to $34 \%$ (Plante \& Jumars 1993) have been reported previously for A. pacifica. However, these findings contrast with the general paradigm established for arenicolid polychaetes which is that they digest bacteria with high efficiency. For example, Grossman \& Reichardt (1991) estimated numerical losses of total bacteria to be between 80 and $90 \%$ for A. marina. Overall, bacterial removal by deposit-feeder digestion is moderately to highly efficient among diverse deposit-feeding taxa (Cammen 1980, Grossman \& Reichardt 1991, Plante \& Jumars 1993). However, comparisons among studies are not always equivalent, due to methodological differences used to quantify bacterial removal (e.g., direct counts vs fatty-acid analyses), as well as the potential to underestimate bacterial growth in posterior gut regions.
Digestion was not affected by temperature and sediment mixture. This is not surprising, as neither affected bacteriolytic rates in vitro (Hymel \& Plante 2000). As with the bacteriolytic data, enormous variability among individuals within treatments, as well as among treatment groups, was evident. This is not to say that qualitative effects on bacterial digestion are necessarily independent of various temperature and food concentration regimes. In addition, differential digestion of bacteria by deposit feeders has been amply demonstrated (Dobbs \& Guckert 1988, Grossman \& Reichardt 1991, Ward-Rainey et al. 1996). The story is further complicated when the functional (i.e., feeding rate) responses of the deposit feeder to temperature and food concentration are superimposed onto the above scenario. Feeding rates and gut residence times certainly influence the rate and duration of bacterial exposure to lytic agents (Plante et al. 1996).

No significant increase in bacterial abundance from MG to HG was detected in the pooled data set. These findings corroborate those of Plante \& Jumars (1993), which indicated that further numerical losses occurred more frequently than increases between the MG and HG of Abarenicola pacifica. They attributed the lack of growth to the fairly rapid gut throughput times (GTT) for A. pacifica. In contrast, significant HG growth has been documented for the closely related Abarenicola vagabunda (Plante et al. 1989), where median growth was 1679 and $6137 \%$ for 2 environmental bacterial isolates. HG growth has also been documented in deposit feeders with fairly long GTTs, such as Arenicola marina (Grossman \& Reichardt 1991), gastropods (Juniper 1981), holothuroids (Deming \& Colwell 1981), decapod crustaceans (Harris 1993), and terebellid polychaetes (Duchêne et al. 1988).

The apparent lack of temperature effects was somewhat unexpected, as bacterial growth often varies directly with temperature in situ (e.g., Meyer-Reil 1986). However, sediment mixture was a much more important influence in HG growth, with an overall significant increase in abundance detected only for the $100 \%$ sediment treatments. Since most detrital material in sediments is refractory to deposit-feeder digestion (Yingst 1976), much of this organic material may thus pass into the HG incompletely digested. In addition, products contributed by the animal to gut contents during processing (e.g., residual enzymes, nonabsorbed digestive products, sloughed gut cells; Mayer et al. 1997) would augment the pool of organic material available to surviving bacteria. As a result, bacteria surviving MG passage would be presented with abundant food resources, reduced microbial competition and physical separation from potentially limiting environmental conditions otherwise experienced in situ. Therefore, we predict that under conditions in 
which more detrital material enters the gut (i.e., high food concentrations), HG bacterial growth would be favored.

As with selection and digestion, no discussion of growth would be complete without addressing the importance of feeding rate and GTT. In general, HG growth of bacteria occurs at little 'cost' (Plante et al. 1990) to the deposit feeder, as absorption of digestive products has previously taken place 'upstream'. The deposit feeder may in fact benefit from a further breakdown of HG material in the form of volatile fatty acids and vitamins that can be absorbed across the gut wall (Phillips 1984). For the present work, however, no clear pattern emerged with respect to feeding rates and growth, as growth was usually not significant within or among individual treatment groups.

Questions regarding quantitative and qualitative effects of deposit feeding remain at the forefront of understanding sediment bacterial ecology. We have observed that temperature and sediment food concentration profoundly affect feeding rates of deposit feeders (Hymel \& Plante 2000). Furthermore, ample evidence exists for selective bacterial removal during gut passage, as well as the potential for enrichment of bacteria within the hindgut. Thus, under low food conditions we expect the greatest quantitative impacts on sedimentary bacteria. On the other hand, the combination of high feeding rates and digestive efficiencies, as well as differential digestion and hindgut growth, should result in greater qualitative impacts. Given our observations here of selective feeding on bacteria-rich sediment fractions, it is clear that seasonal influences on deposit feeders will also indirectly impact sediment bacteria.

Acknowledgements. We thank C. Czeilsa, L. Flinn, B. Hentschel, L. Iocco, J. Millard, R. Terwilliger and S. Wilde for field and laboratory assistance. J. Fauth, A. McCallum and L. Zimmerman provided statistical advice. Additional facilities and equipment were furnished graciously by the NOS and MRRI laboratories of Charleston, SC, as well as by G. DiTullio. Comments by K. Carman and 2 anonymous reviewers were helpful in earlier drafts of the manuscript. Funding was provided by NSF grant OCE95-04505 (to C.J.P.). This is contribution 174 of the Grice Marine Laboratory.

\section{LITERATURE CITED}

Alongi DM (1988) Bacterial productivity and microbial biomass in tropical mangrove sediments. Microb Ecol 15: 59-79

Bianchi TS, Levinton JS (1984) The importance of microalgae, bacteria and particulate organic matter in the somatic growth of Hydrobia totteni. J Mar Res 42:431-443

Cammen LM (1980) The significance of microbial carbon in the nutrition of the deposit feeding polychaete Nereis succinea. Mar Biol 61:9-20
Cammen LM, Walker JA (1986) The relationship between bacteria and micro-algae in the sediment of a Bay of Fundy mudflat. Estuar Coast Shelf Sci 22:91-99

Danovaro R, Fabiano M, Boyer M (1994) Seasonal changes of benthic bacteria in a seagrass bed (Posidonia oceanica) of the Ligurian Sea in relation to origin, composition and fate of the sediment organic matter. Mar Biol 119:489-500

DeFlaun MF, Mayer LM (1983) Relationships between bacteria and grain surfaces in intertidal sediments. Limnol Oceanogr 28(5):873-881

Deming JW, Colwell RR (1981) Barophilic bacteria associated with deep-sea animals. BioScience 31:507-511

Dobbs FC, Guckert JB (1988) Microbial food resources of the macrofaunal-deposit feeder Ptychodera bahamensis (Hemichordata: Enteropneusta). Mar Ecol Prog Ser 45: $127-136$

Duchêne JC, Imbaud P, Delille D (1988) Associated bacterial microflora of a subantarctic polychaete worm Thelepus setosus. Arch Hydrobiol 112(2):221-231

Ducklow HW (1983) Production and fate of bacteria in the oceans. BioScience 33:494-501

Findlay RH, White DC (1983) The effects of feeding by the sand dollar Mellita quinquiesperforata (Leske) on the benthic microbial community. J Exp Mar Biol Ecol 72:25-41

Grossman S, Reichardt W (1991) Impact of Arenicola marina on bacteria in intertidal sediments. Mar Ecol Prog Ser 77: 85-93

Harris JM (1993) Widespread occurrence of extensive epimural rod bacteria in the hindguts of marine Thalassinidae and Brachyura (Crustacea: Decapoda). Mar Biol 116:615-629

Hobson KD (1967) The feeding and ecology of two North Pacific Abarenicola species (Arenicolidae, Polychaeta). Biol Bull 133:343-354

Hughes RN (1980) Optimal foraging in the marine context. Oceanogr Mar Biol Annu Rev 18:423-481

Hylleberg J (1975) Selective feeding by Abarenicola pacifica with notes on Abarenicola vagabunda and a concept of gardening in lugworms. Ophelia 14:113-137

Hymel SN, Plante CJ (1998) Improved method of bacterial enumeration in sandy and deposit-feeder gut sediments using the fluorescent stain 4,6-diamidino-2-phenylindole (DAPI). Mar Ecol Prog Ser 173:299-304

Hymel SN, Plante CJ (2000) Feeding and bacteriolytic responses of the deposit feeder Abarenicola pacifica (Polychaeta: Arenicolidae) (Healy and Wells) to changes in temperature and sediment food quality. Mar Biol (in press)

Juniper SK (1981) Stimulation of bacterial activity by a deposit feeder in two New Zealand intertidal inlets. Bull Mar Sci 31(3):691-701

Kemp PF (1990) The fate of benthic bacterial production. Rev Aquat Sci 2:109-124

Levinton JS, Stewart S (1988) Effects of sediment organics, detrital input, and temperature on demography, production and body size of a deposit feeder. Mar Ecol Prog Ser 49:259-266

Lorenzen CJ (1966) A method for the continuous measurement of in vivo chlorophyll concentration. Deep-Sea Res $13: 223$

Lucas F, Bertru G (1997) Bacteriolysis in the gut of Nereis diversicolor (O.F. Muller) and effect of the diet. J Exp Mar Biol Ecol 215:235-245

Mayer LM, Schick LL, Sawyer T, Plante CJ, Jumars PA, Self RL (1995) Bioavailable amino acids in sediments: a biomimetic, kinetics-based approach. Limnol Oceanogr 40(3): 511-520

Mayer LM, Schick LL, Self RFL, Jumars PA, Findlay RH, 
Chen Z, Sampson S (1997) Digestive environments of benthic macroinvertebrate guts: enzymes, surfactants and dissolved organics. J Mar Res 55:785-812

Meyer-Reil LA (1986) Spatial and temporal distribution of bacterial populations in marine shallow water surface sediments. In: Lasserre P, Martin JM (eds) Biogeochemical processes at the land-sea boundary. Elsevier, Amsterdam, p 141-160

Meyer-Reil LA, Bölter M, Dawson R, Liebezeit G, Swerinski H, Wolter K (1980) Interrelationships between microbiological and chemical parameters of sandy beach sediments, a summer aspect. Appl Environ Microbiol 39(4): 797-802

Moriarty DJW (1982) Feeding of Holothuria atra and Stichopus chloronotus on bacteria, organic carbon and organic nitrogen in sediments of the Great Barrier Reef. Aust J Mar Freshw Res 33:255-263

Moriarty DJW (1989) Relationships of bacterial biomass and production to primary production in marine sediments. In: Hattori T, Ishida Y, Maruyama Y, Morita RY, Uchica A (eds) Recent advances in microbial ecology. Proc 5th Int Symp Microb Ecol (ISME5). Japan Scientific Societies Press, Tokyo, p 349-354

Newell R (1965) The role of detritus in the nutrition of two marine deposit feeders, the prosobranch Hydrobia ulvae and the bivalve Macoma balthica. Proc Zool Soc Lond 144: $25-45$

Phillips NW (1984) Role of different microbes and substrates as potential suppliers of specific, essential nutrients to marine detritivores. Bull Mar Sci 35(3):283-298

Plante CJ, Jumars PA (1993) Immunofluorescence assay for effects on field abundance of a naturally occurring pseudo-

Editorial responsibility: John Dolan,

Edgewater, Maryland, USA monad during passage through the gut of a marine deposit feeder, Abarenicola pacifica. Microb Ecol 26:247-266

Plante CJ, Mayer LM (1994) Distribution and efficiency of bacteriolysis in the gut of Arenicola marina and three additional deposit feeders. Mar Ecol Prog Ser 109:183-194

Plante CJ, Mayer LM (1996) Seasonal variability in the bacteriolytic capacity of the deposit feeder Arenicola marina: environmental correlates. Aquat Microb Ecol 11:101-109

Plante CJ, Jumars PA, Baross JA (1989) Rapid bacterial growth in the hindgut of a marine deposit feeder. Microb Ecol 18:29-44

Plante CJ, Jumars PA, Baross JA (1990) Digestive associations between marine detritivores and bacteria. Annu Rev Ecol Syst 21:93-127

Plante CJ, Mayer LM, King GM (1996) The kinetics of bacteriolysis in the gut of the deposit feeder Arenicola marina. Appl Environ Microbiol 62(3):1051-1057

Retraubun ASW, Dawson M, Evans SM (1996) Spatial and temporal factors affecting sediment turnover by the lugworm Arenicola marina (L.). J Exp Mar Biol Ecol 201: 23-35

Scheirer CJ, Roy WS, Hare N (1976) The analysis of ranked data derived from completely randomized factorial designs. Biometrics 32:429-434

Sokal R, Rohlf F (1995) Biometry. WH Freeman and Co, San Francisco

Ward-Rainey N, Rainey FA, Stackebrandt E (1996) A study of the bacterial flora associated with Holothuria atra. J Exp Mar Biol Ecol 203:11-26

Yingst JY (1976) The utilization of organic matter in shallow marine sediments by an epibenthic deposit-feeding holothurian. J Exp Mar Biol Ecol 23:55-69

Submitted: December 14, 1999; Accepted: May 3, 2000

Proofs received from author(s): July 7, 2000 